\title{
\begin{tabular}{ccc}
\hline 技 術 紹 & 介 \\
\hline
\end{tabular} \\ 凍度計とその利用について
}

赤 星 亮 一

現代の工業にあって, 工梨管理に, 品質検査に, 計測 の重要性はいうまでもない。自動制御またしかりであ る。化学工業においても，その製造機械装置は，日を打 って進歩し, 各種の精溜㙨, 反応装置怯自働化され，面 目を一新したかたちである。しかしながら，化学物質に 関する計測户，自動制御は，電子工業や，機械工業のそ れに比較して容易でない。

このように，成分の簡単な物質を取扱う場合であ化学 的な性質定電気的な量に変換することは，なかなか大变 な仕事である。われかれの食品工業で取报かうすのは， もっと複雑な天然物質であるので，品質や工程の管理に どのような性質をとりあげて，どのように表示するかと いうことは，まことに容易でない。しかし，対象とする 試料の物理化学的特性をよくしらべそれを検出し，電気 的な量に変換表示できるよう努力するならぼ，大いに 有用な成果が期待される。さて，食品工業に関連する計 测々制御について，身近かな問題を論じてみよう。ま 一”，食品を生産し貯蔵する場所，環境，条件の管理に必 梁なものでは温度，湿度，などの計測，制御がある。つ ぎに食品を製造する工程の管理に必要な水分や，濃度， など配合成分の調節，流量の測定，調理効果の測定，の ちにのべる冷凍食品の凍結度の測定などがあげられる。 それから最後に生産物の品質管理の問題がある。すなる ち，色，光沢，香り，硬さ，粘弾性，などの測定や，生 産物に対する迅速機器分析などである。これら環境, 条 件，工程，品質，なぞの管理に叔ける計測，制御の意義 はきわめて大きく, 今後の食品工業界の重要課題の 1 つ である。さて，前述したごとく計測と制御のキーポイン トは, 試料の物理化学的特性のピックアップと, 電気的 諸量への変換表示であり，その方式はそれぞれの測定目 的にかなうう非常に多種多栐に研究されている。いま ここにそれらを詳述することはまずおくとして，今回は
とくに問題となる意味から，冷凍食品の谏絬度它表示す るに適した淉度計について紹介してみたい。

技術革新のとき定迎えた，わが食品工業界にあって， とくに顕著な進出を見せているのが冷谏食品で西る。食 品の冷凍の基璴理諭や応用については内外の研究者や技 術者によってすでに多数の研究がある。しかし，本格的 な冷涷食品時代に対応して，食品の涷結工程を管理する 計測器や記録計は全くなく，絟験によって得られた冷葴 や倲結の方式が用いられている。著者の研究室では昨年 以来, 食品の凍結度をその誘電性の変化から表示名新 計測装置を考案し試作中であったが，実験の結果，試料 の凍結状態学鋭敏に知ることができ，自由水の水結や結 合水の dehydration, 水結について興味ある知見を得る ことができた。ここにその概要を紹介する次第である。 な扮詳細化ついては，近く学会誌につぎの研究報交を投 熇する予定であるので参照されたい。赤星亮一, 堀家静 子, 「食品の凍結状態に関する研究（第 1 第 3 報）」。

1. 冷凍に伴う食品性状の変化

現在行なるれている冷凍の方式位, 空気凍結, 送風凍 結，金属板接強凍結，2次冷媒凍結などがあり，また凍 結の速度により急速凍結, 縵速凍結の別がある。これら 冷却方式の相違により，食品によっては凍結後の性質や 状態が大きく変化し, 凍結による蛋白の変性, 氷結晶に よる食品組織の破壊がおこる。これらは解凍の際のドリ ップを増加せしめ，食品の質を劣化させるので，食品の 種類に適した冷却法式が工夫されている。いま,ここ に, 冷却に伴う食品の性状の変化考えてみよう。冷却 されるにしたがって，食品の温度が下り水分の凍結が始 まる。食品中の水分は自由水と結合水上りなり，それぞ れ塩類を溶解しているので涷結は $-1{ }^{\circ} \mathrm{C}$ 位から始をる。 結合水注, 食品中の蛋白, 炭水化物に束縛されている 水であって，束縛のされ方が強いほE゙谏りがたいが，自

* 東洋大学工学部（埼玉県川越市鮊井中野台 2100） 


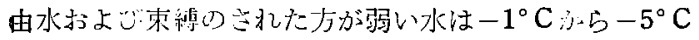

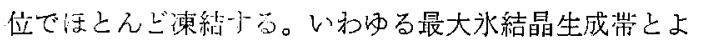
ばれる温度簕囲である。ゆるやかな速度で冷凍する場合

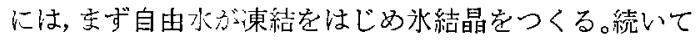
束䋠のされ方が弱い潐結合水が細胞組織や蛋白や炭水化 物などの物質からは尔れて氷結晶の成長に加わり，その

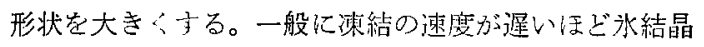
の大きさが大きくなり, 食品の組織炎いためるぶ，急速 冷涷においては一斉に倾細な氷結晶が出現し，食品の組 織中にできる空孔の帅状も小さく，品質をいためない。 一般に自由水の双が水結している場合には，解凍寸狆ば もとの状態に復子るが，結合水未で凍結した場合には， 解凍しても元に復今沈いとされている。こ礼は脱水され た蛋白の分子構造が变化するため，解湅しても元に復さ ない名らだしされている。もし冷凍の速度がきかめて速 $く$, 結合水領域の水分它, 蛋白などの食品組織加ら,

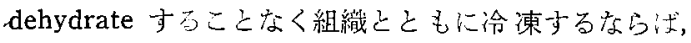
变性の程度も少なく，良好な品質を保つことができると 考えられる。さて，この食品の倲結度を，なんらかの計 器で測定することがー゙きるならば, 食品冷凍の基礎研究 のみでなく、食涷工業における工程管理, 制御などに役 立つでからう。一般に計測器は, 試料の物理化学的性状 の変化在なえらふの電気的量に变換し得て始めて成立す る。著者らが試作開発した凍度計は, 冷凍に伴う誘電性 の変化劣利用したものた，試料中の分子の mobility 明確に知ることがで羔るのが特幑である。

\section{2. 凍度計の原理とその機構}

(1) 物質の誘電性

よく知られているように，物質には無極性の物質こ有 極性の物質がある。これらの物質が電場におか狆たとき には各種の分極を起こし，とくに有極性分子は電場に配 向しようとして迴転運動を生ずる。この分子の配向は, 温度により左右される。すなわち1つ注，分子の配向定 さまたげる熱運動の影響であり，いま1つは，電場に配 向しようとする分子の mobility の問題である。前者は 温度が高くなればなるほど熱運動が活発になり分子の配 向が妨げられるが，後者はその物質本来の性質によって きまるもので，分子の構造，分子間の相互作用，分子に 働く力などによって配向の難易がきまる。いずれにせ よ，双極子の配向は温度の影望䆜受けるので，物質の誘 電性も温度により大きくかわる。すなわち, 温度に対応 する双極子の mobility が配向の難易を決定し，物質の 誘電性を支配するわけである。低温になると熱運動は減 少するが，一方，分子間为は増大し，分子の mobility
は、だえだん少なくなるので，誘電㮦は隇少する。つい に凍結状態になると，分子の配向はきわわて困難で誘電 率は激減する。これらの関係它図示したものか第 1，2 図で誘電蜜 $\varepsilon^{\prime}$ の値は周波数 $f$ と温度 $T$ によること

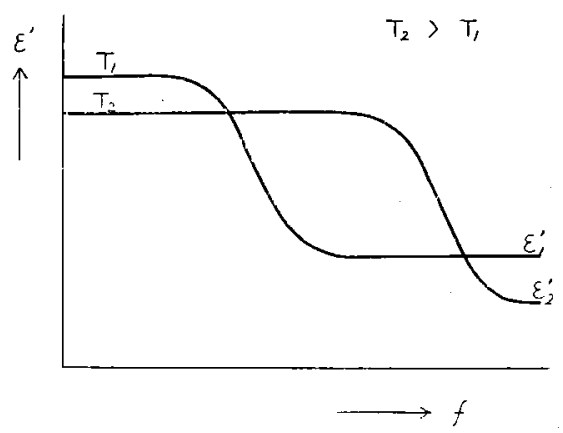

第 1 图 a 2 つの温度 $T_{1}, T_{2}\left(>T_{1}\right)$ k対する $\varepsilon^{\prime}$ と振動数 $f$ との関係

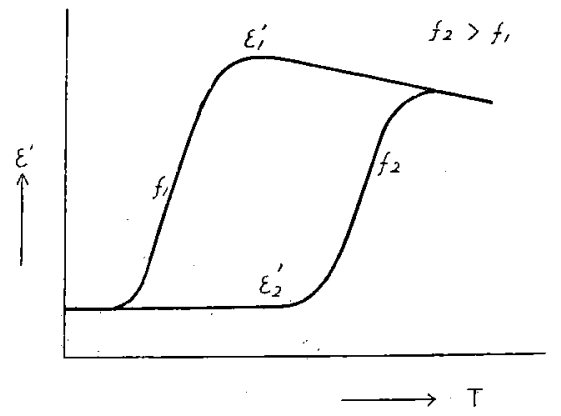

第 1 図 $\quad \mathrm{b} \quad 2$ つの振動数 $f_{1}, f_{2}\left(>f_{1}\right)$ に対する $\varepsilon^{\prime}$ と湿度との関倸

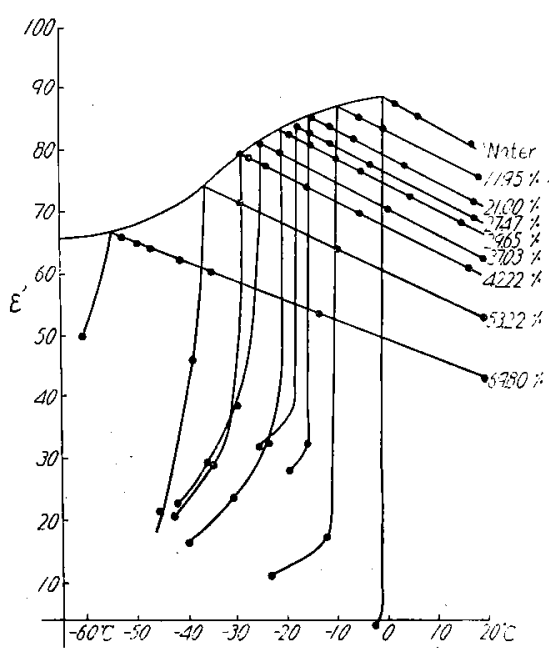

第2図フルコール水溶液の誘電率 
を示している。すなわら $T$ が一定の場合には（第 1 図 a) $f$ が低い間は双極子の配向が十分に行なわれ， $\varepsilon^{\prime}$ の傎が大きく，f が大きくなるにつれて，双極子の配向 が困難になり， $\varepsilon^{\prime}$ の值が，ある周波数 領 域で大きく変 化し減少する。この周波数に対応する誘電率の変化を, 誘電率の周波数分散と呼ぶ。一般に，この分散を沶こす 周波数領域は，温度が低いほど低周波側にずれる。ま た，周波数 $f$ が一定のときの誘電率の温度変化を低温側 への変化についてながめると，第 1 図bに示すごとく， 高温における熱運動による双極子配向の管害は低温にな

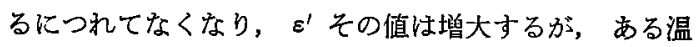
度になると分子の mobility が減少して， $\varepsilon^{\prime}$ の值が減少 するのは前述のごとくである。第 2 図は水および酒精水 溶液の誘電卒の温度変化を図示したもので，凍結点にお ける锐敏な変化や，凍結後の分子の mobility がよくあ らわされている。

(2) 凍度計の原理と機满

i ) 電気容量と誘電率

物侗の誘電性は，われわれが日常取报う物理的な量の 1つであり，電気容量の值を決定的に支配する。すなわ ち，第 3 図に示すごとく，ある一定面䅡，一定間隔の極 板間に交流電圧 $V$ を与えたとき，極板内の蓄電器につ め込まれたり，引き出されたりする電荷を $\boldsymbol{Q}$ とする。 電極間の媒質が真空のときを $Q_{0}$ とし，電極間の媒質が 物質 $A$ であるときを $Q_{A}$ とする。この場合 $Q_{A}$ と $Q_{0}$ の比を物質 $A$ の誘電染とよび，(1) 式であらわされる。

$$
\boldsymbol{\varepsilon}^{\prime}=\frac{Q_{A}}{Q_{0}}
$$

交流電圧 $V$ は (2) 式のごとく，また $Q_{0}$ は (3) 式の ごとくあらわされるので，Q0の時間的な変化，すなわ ち, 電流 $I_{0}$ は (4) (5) 式のごとくあらわすことがて きる。

$V=V_{0} \sin \omega t$ volt
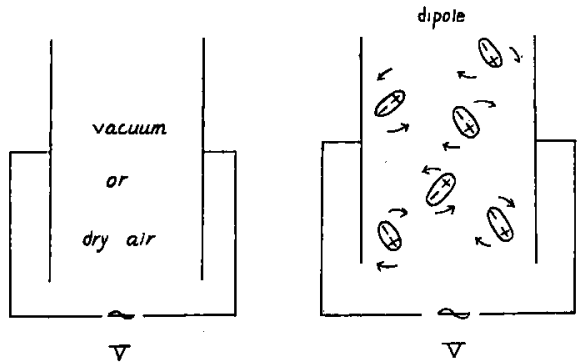

第 3 図電極間の双極子配向

$$
\begin{aligned}
& Q_{0}=C_{0} V \text { coulomb } / \mathrm{cm}^{2} \\
& I_{0}=\frac{d Q_{0}}{d t}=C_{0} V_{0} \omega \cos \omega t \\
& I_{0}=C_{0} V_{0} \omega \sin \left(\omega t+\frac{\pi}{2}\right)
\end{aligned}
$$

物質 $A$ 名電極間の媒質として存在する場合は，同様にっ

$$
\begin{aligned}
Q_{A} & =C_{A} V \text { coulomb } / \mathrm{cm}^{2} \\
I_{A} & =\frac{d Q_{A}}{d t}=C_{1} V_{0} \sin \left(\omega t+\frac{\omega}{2}\right)
\end{aligned}
$$

である。ここに $C_{0} ， C_{A}$ はそれぞれ電極間の媒質が真空 （または乾燥した空気）およど $A$ の場合の電極間の電気 容量である。

物質 $A$ の誘電率 $\varepsilon^{\prime}$ は，これらの関係汃ら，

$$
\varepsilon^{\prime}=\frac{Q_{A}}{Q_{0}}=\frac{I_{A}}{I_{0}}
$$

この $I_{0} ， I_{A}$ は，それぞれの場合に単位㭙間に電極間 に出入する電荷量であって，変位電流とよばれる。変位 電流 $I$ は (5) (7) に示されるとおり, 電圧 $V$ の位相上 り $90^{\circ}$ 進えだ位相で流れる。翋位電流は晋通の渞電々流 （V と同位相）と䔔って媒質が理想的誘電絶縁体である 場合には熱損失を生じない。しかし極性分子の迴耺に俳 うェネルギー損失のため $V$ と同位相の損失を生ずる。 ゆえに, 複素誘電率 $\varepsilon$ は一般に

$$
\varepsilon=\varepsilon^{\prime}-i \varepsilon^{\prime \prime}
$$

であらわされ，実数部 $\varepsilon^{\prime}$ (誘電率) と虚数部 $\varepsilon^{n}$ (損失 率とよりなり，

$$
\varepsilon^{\prime \prime}=\varepsilon^{\prime} \tan \delta
$$

なる関係がありすは電流のベクトルがどれだけ変位電 流の位相から遅れているか，その位相差の角度である。

ii）食品試料の電気的性質

われわれの対象とする食品試料は决して琹想的な誘電 絶緑体ではなく, 上記のdの角度は大きく, 誘電損失が 大きい。また，多量の電解質を含むので，变位電流ばか りでなく，大きな導電々流が流れる。すなわち，食品試 料を媒質として電極間においた場合, 流れる電流を $I$ と すると，Iはつきのようにあらわすことができる。

$$
I=I_{C}+I_{R}
$$

ここに

$$
I_{C}=j \omega C V \quad \text { （変位電流） }
$$




$$
I_{R}=\frac{V}{R} \quad \text { (䆃電電流) }
$$

$\omega$ は電源の角周波数， $C, R$ はそれぞれ電極䦐の電気 容量と電気抵抗である。

$$
I=\left(j \omega C+\frac{1}{R}\right) V
$$

iii）測定方式と電源周波数の決定

凍度計として，計測の対象となるのは，(11）(12）式 の示すとおり，電極間の試料の電気容量と電源周波数の 相乗積に比例する。変位電流 $I_{C}$ と, 試料中の電解質の 電離にもとずく導電々流 $I_{R}$ である。この $I_{C}$ は前述の ごとく，双極子配向の mobility を示すむのであり，試 料の凍結状態と密接な関係がある。 $I_{R}$ も試料中の水分 が凍結し電解質に対して，溶媒の役目を果さなくなれ 将，電気伝導度が減少するので，凍結状態を示す指標と なる。しかし，凍結に伴う分子の mobility の变化を適 確に知り，表現するためには $I_{C}$ 主主体に計測する必要 がある。したがって電源の周波数が高く, $j \omega C 》 1 / R$ で あることが望ましい。現実的には試料中に挿入された電 極から, 計測器までの導線の impedance が問題となる ので，電源周波数をあまり高くすることができず，実際 には $1 \sim 10 \mathrm{KC}$ 程度が適当である。 $I_{C} や I_{0} を ，$ 高周 波電流計などを用いて，そのまま測定することは適当で ないので，著者はつぎのような測定方式を採用した。

第4図において， $R_{X} ， C_{X}$ 壮試料の impedance 定, 抵抗と reactance にわけて，表示したあのである。 $R_{m}$ は $R_{X}, C_{X}$ に直列に接続された既知抵抗である。 $A B$ 間に一定の電圧 $V_{S}$ を与え, $R_{m}$ の両端の電压 $V_{m}$ 索真空管電圧計で測定し， $R_{X}, C_{X}$ を流れる電流 $I_{R}, I_{C}$ のベクトル和を知るうとするものである。すなおち， $\boldsymbol{R}_{\boldsymbol{m}}$ 学流れる電流を $I_{m}$ とすると,

$$
I_{m}=\frac{V_{m}}{R_{m}}=\sqrt{I_{R^{2}}+I_{C^{2}}}
$$

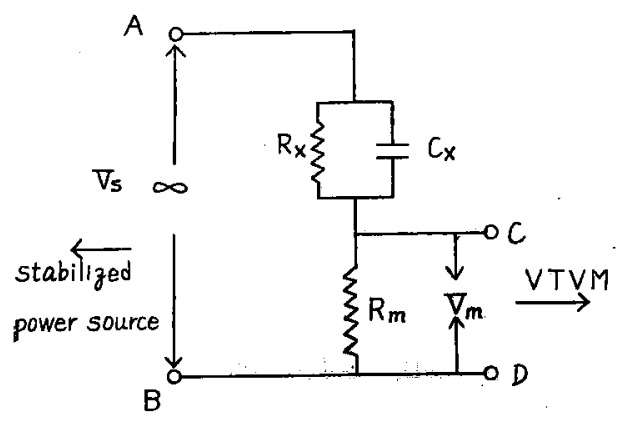

第 4 図

$$
=\left(V-V_{m}\right) \sqrt{\frac{1}{R_{X}{ }^{2}}+\omega^{2} C_{X^{2}}}
$$

である。 $V_{m}$ を測定することにより，電極間の試料の impedance（あるいは admittance）を知ることができ るが, 真空管電圧計上に, impedance や admittance の值を目盛ることにより，直読することも可能である。

iv) 測定回路の block diagram

第 5 図に示すごとく，安定 $A B$ 電源，安定高周波笔 源, 測定回路, 直読 admittance meter (真空管電圧計) の4 部分より棰成される。また，admittance meter を 記録計に接続することができる。

v）凍結に伴う試料の admittance の变化

第 6 図は，純水の 凍結に伴う admittance Y の変化を 図示したものである。この場合には電気伝導度はきわめ て小さいので，1/R は無視してょく， admittanceは $j \omega C$ のみとなる。前述したごとく，純水は液体にあっ ては，温度が下がると誘電率の值は堌加するが，凍結点 に達すると分子の配向が困難になって，急激に減少する

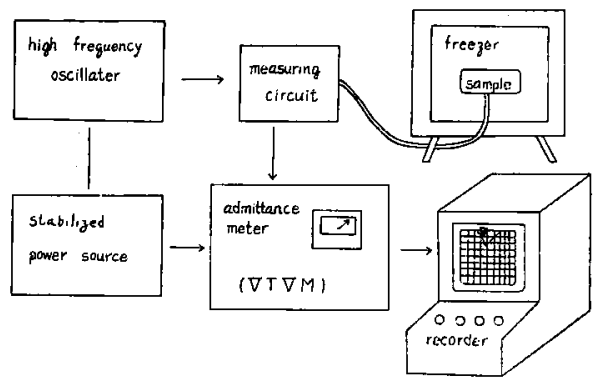

第 5 図 block diagram of freezing meter

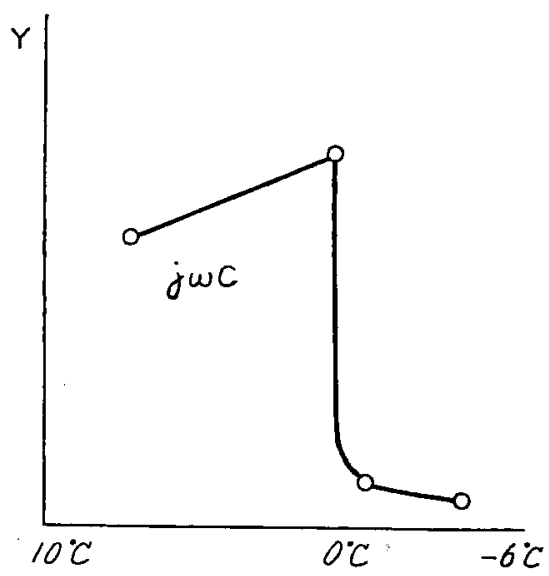

第 6 図凍結に伴5 admittance の变化(純水 の場合） 


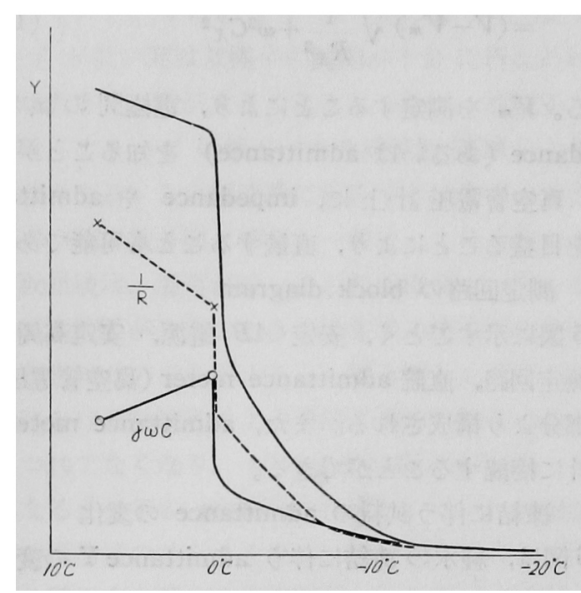

第 7 図凍結に伴う admittance の変化（自由小， 結合水和よび電解質を含む試料の場合）

\section{ことを示している。}

第 7 図は食品試料の凍結に伴う变化をモデル化して図 示したものである。すなわち，電気伝導度は，温度が下 がるにつ机て小さくなるので，1/R は図のとおり低下 する。また $j \omega C$ は上昇する。相速冷凍の場合には， 自由水が凍結をはじめ， $1 / R$ および $j \omega C$ は急激に減少 するが，結合水は末凍結であるので，ゼロとはならな い。しかし，弱い結合水から順次に凍りはじめ図のごと く減少する。この $1 / R$ および $j \omega C$ が復合されて，実 際の admittance は太い実線のごとくなる。

\section{3. 各種食品における凍度計の実験例}

著者らが試作した凍度計を用い，果実，畜肉，魚肉， 乳製品について，凍結度の測定を行なった数例を示す。 冷凍の方式は，試料をフリーザー中に納め，徐々に品温 を低下凍結せしぬる緩速冷凍方式，あらがじめ $-30^{\circ} \mathrm{C}$ に冷却され，攪拌されているブライン中に入れて，急速

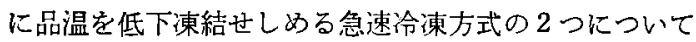
実呀を行なった。

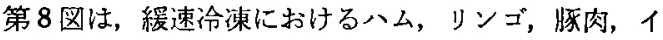
カ, マグロ，チーズの凍結に伴う admittance の変化 を示したものである。橫慙に温度を,縱軕に admittance をとり， $\mu \mathrm{F}$ の単位で図示した。リンゴの場合に限って 紙面に向って右の縦軸の尺度で示してある。第 9 図は同 様に，急速冷凍における各種食品の admittance の変 化を図示したものである。緩速冷凍においては，第 6 図 の理論曲線のごとく，自由水，結合水の凍結に伴う admittance の変化があらわれている。急速冷凍の場合 との比較を各食品についてみるとつぎごとくである。

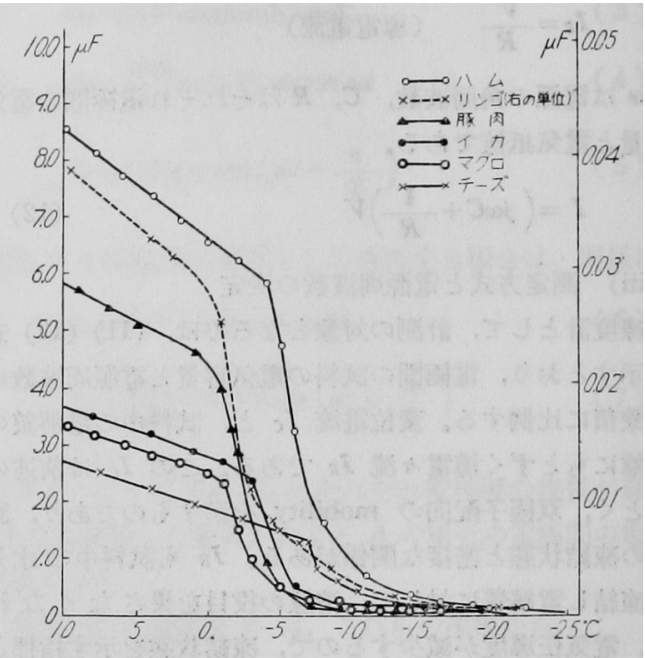

第 8 図凍結に伴う admittance の変化 （縟速冷谏）

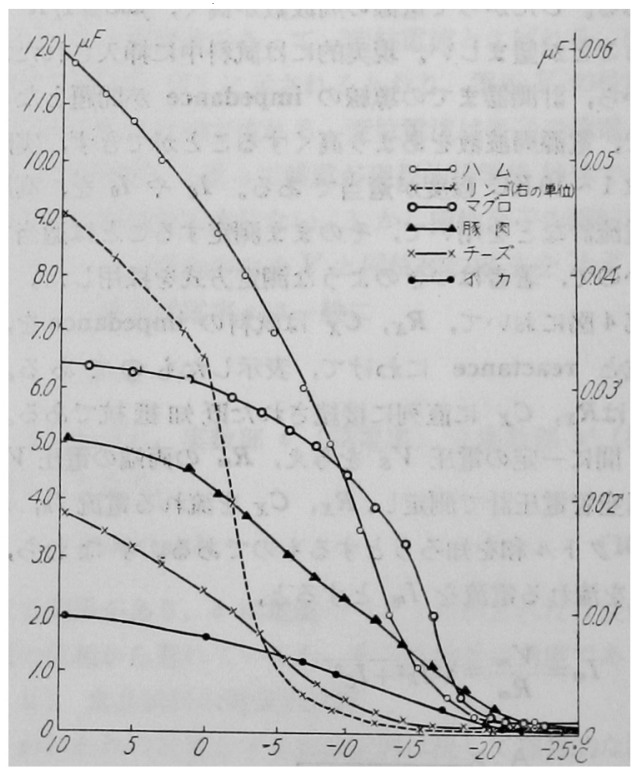

第 9 図凍結に伴う admittance の変化 （急速冷凍）

ここに admittance の值は試料中に挿入した電㥛間のも ので, 温度娬料内部の温度である。

(1) リンゴ (第 10 図)

緩速冷凍の場合も，急速冷凍の場合もほとえど差はな い。これはリンゴの成分中水分が $87 \%$ を占め， その大 部分が自由水であることにもとずく。しかし，詳しく検 討すると, $-5^{\circ} \mathrm{C}$ からー15 $\mathrm{C}$ にあたって水結する水分 


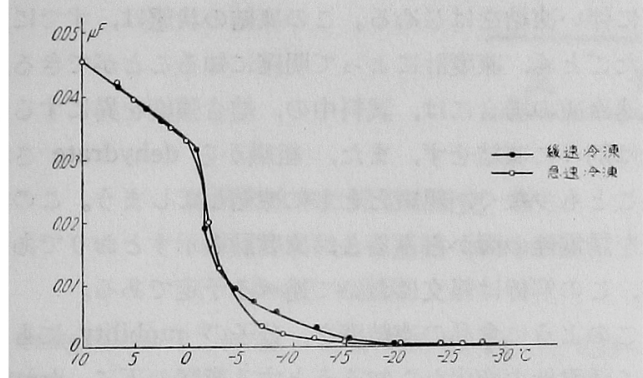

第 10 図 リンت゙（水分 $86.7 \%$ )

があり，この水分は常温においては組織に結合している が, 承結の際組織から離れて氷結晶を生成するので，一 度永結したリンゴは，組織が破壊されて，復元しない。

（2）八么(第 11 図)

緩速冷凍の場合には，まず $-5^{\circ} \mathrm{C}$ から $-8^{\circ} \mathrm{C}$ におい て自由水が水結し，つきにに $-20^{\circ} \mathrm{C}$ にかけて結合水が水 結することがわかる。これに反し急速冷凍の場合は，独 特の変化を示している。この温度-admittance 曲線の 意義を解析することは容易でないが, 自由水, 結合水, 組織が急速に同時に凍結していると推定される。ここに $10^{\circ} \mathrm{C}$ から $-20^{\circ} \mathrm{C}$ に冷却するに要する時間は，綑速冷 凍の場合 450 分，急速冷涷の場合 20 分である。試料中 の全水分は $56.9 \%$ である。

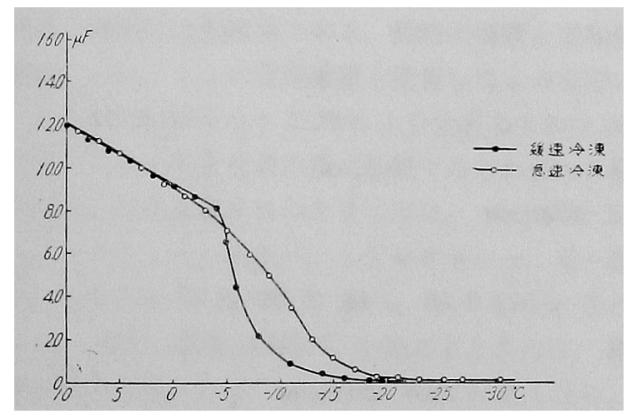

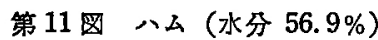

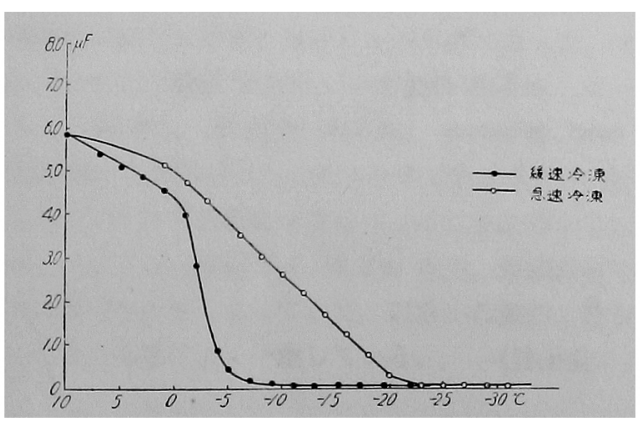

第 12 図 豚肉（水分 $73.7 \%$ )
（3）豚肉（第 12 図）

この場合は水分が多く，73.7\%で，八厶に比較して， 繹速冷凍之急速冷凍の凍結状態の差著しい。緩速冷谏 の曲線からかかるとおり，自由水は $-1^{\circ} \mathrm{C}$ から $-4^{\circ} \mathrm{C}$ の領域で水結し，結合水はそれ以下の温度で水結する。 $10^{\circ} \mathrm{C}$ から $-20^{\circ} \mathrm{C}$ までの冷却時問は緩凁冷凍, 急速冷 凍それぞれ 480 分，55分であった。

(4) イカ（第 13 図）

水分は $70.8 \%$ で豚肉の凍結状態と同じである。 $10^{\circ} \mathrm{C}$ から $-20^{\circ} \mathrm{C}$ までの冷却時間は綫速冷凍，急凍冷凍そ れぞれ253 分, 17 分である。

（5）マグロ(赫味肉)（第 14 図）

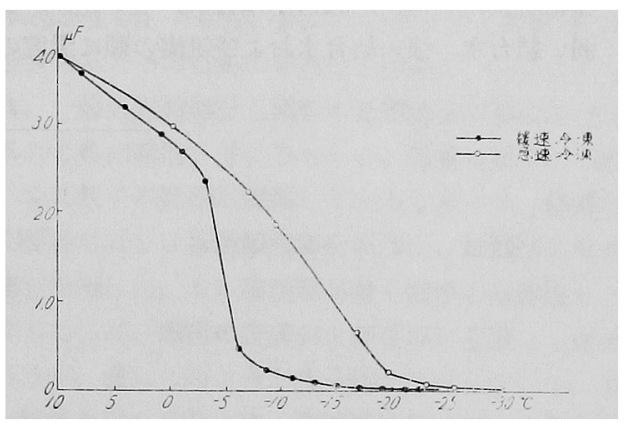

第 13 図 イカ（水分 $70.8 \%$ )

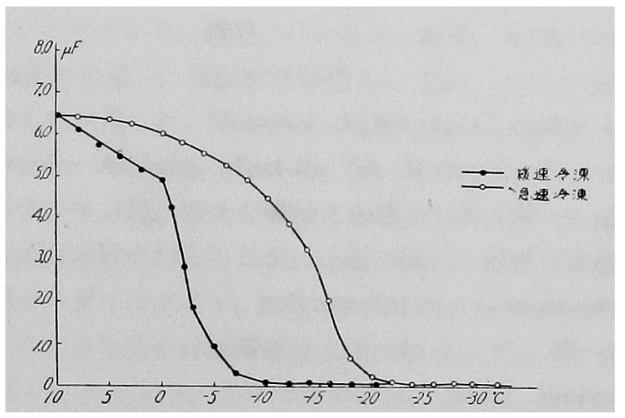

第 14 図 マダロ（水分 $71.9 \%$ ）

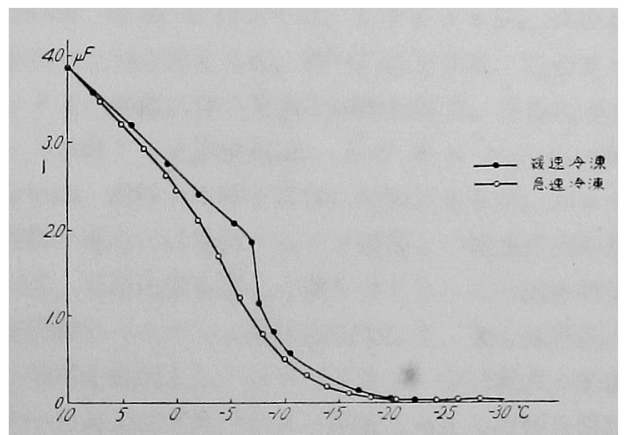

第 15 図 チーズ（水分 $38.5 \%$ ) 
水分は $71.9 \%$ で，豚肉，イカに此較して，冷凍方式 の差異にもとずく凍結状態の差は，さらに大きい。1 $10^{\circ} \mathrm{C}$ から $-20^{\circ} \mathrm{C}$ までの冷却時間壮䌅速冷涷，急速冷涷それ でれ 273 分, 19 分である。

（6）チーズ(第 15 図）

水分は $38.5 \%$ で，緩速冷凍の場合でも， $-7^{\circ} \mathrm{C}$ では じめて凍結がはじまる。完全な自由水は少なく，蛋白や 炭水化物比束縛された水分の多いことがわかる。1 $10^{\circ} \mathrm{C}$ から $-20^{\circ} \mathrm{C}$ までの冷却時間は緩速冷凍の場合 155 分, 急速冷涷の場合には 20 分である。

4. むすび

以上のように，食品試料を徐々にゆるやかな速度で冷 却，凍絬する場合には，試料中に合をれる水分は，自由 水，弱い結合水，強い結合水および組織の順に温度の降
下に伴い凍結をはじめる。この凍結の状態は，すでに述 ベたごとく，凍度計によって明確に知ることができる。 急速冷涷の場合には, 試料中の, 結合強度を異にする水 分は別々に谏結せず，また，組織から dehydrate され ることも少なく，組織とともに凍結してしまう。この状 況を誘電性の面からみると，凍度計の示すとおりである が，この解析は報交に沶いて述べる予定である。

このように食品の谏結度を，分子の mobility にもと ずく誘電性の变化から知らうとする意図の下に，われわ れは凍度計の開発を行ない実験を試みたところ，幸いに その柬結状態を把握することができた。凍度計につい て, 電極その他計測機構をさらに改良すべく, 現在努力 中である。食品冷湅の基礎研究に，工程管理のために， 不可欠の計測機鄂こ古ると考えている。 